\title{
Trading Voices
}

\section{The Gendered Beginnings of Playback}

At the end of his regular column entitled “This Month's Star" in November of 1944, film magazine editor P. R. S. Gopal included a prediction. Praising the singing actress N. C. Vasanthagokilam's classically trained and "sweet" singing voice and capable acting, he wrote, "One may say that her name will rise very quickly. Because of her acting skill and good training, viewers soon will forget that her face is only so-so." A photo of Vasanthagokilam showed her seated on a bench in a casually draped sari, hands folded: a nonglamorous "off-screen" pose designed to highlight her singing ability rather than her physical allure (Gopal 1944, 18-19).

But Gopal's prediction did not come true. Unfortunately, Vasanthagokilam passed away from tuberculosis in 1951 at the age of thirty. Even if she had lived, however, it is unlikely that her career as a singing actress would have continued much into the 1950s. Viewers did not forget about female beauty; on the contrary, actresses came increasingly to be discussed in terms of their looks. The ability to sing, it was often noted, rarely went together with beauty. And, by the end of the 1940s, what had been an occasional practice-substituting another's voice for that of an actress who could not sing well enough-had become the norm. Known in Tamil as iraval kural, the borrowing or lending of voices, the practice of substituting voices was initially viewed with suspicion, as a form of deceit or vaguely illicit "trade" in voices, but within a decade, came to be viewed as a natural and necessary part of making films. Beginning in the early 1950s, those lending their voices started to be called pinnani pātakarkal (background singers) and began to be credited in films. By the end of the 1950s, they had achieved full-fledged recognition as singers whose skills, careers, and personae were entirely separate from those of actors and actresses, while singing stars had all but disappeared from Tamil cinema.

This chapter examines the period in which the preeminence of singing actors and actresses was eclipsed by the emergence and normalization of the playback 
system. This shift was not simply the result of increased technical capabilities. Rather, the affordances of particular technologies intersected with an emerging discourse about gender, stardom, and respectability formed in relation to a social reform movement that targeted hereditary female practitioners of music and dance as morally degenerate and artistically inferior. The shift to playback was institutionalized in the context of the new sexual economy inaugurated by nationalist modernity-more specifically, by the rise of Dravidian politics and its uptake of cinema as a medium.

The couplings and decouplings of voice and body effected by playback were, from the very beginning, asymmetrically gendered. The practice of using one person's body and another's voice in Tamil films began specifically as a form of experimentation with the combination of female body and singing voice. For nearly a full decade, from the late 1930s to the late 1940s, the male voice and body were not subject to similar manipulation. In the first part of this chapter, I show that the substitution of female voices, as the practice was originally understood, was bound up with anxieties over the respectability of cinema triggered by the figure of the actress and with a moral distinction made between singing and acting. In the 1940s, actresses were increasingly viewed as fragmentable entities, discussed in terms of acting, singing, and dancing capabilities, as well as looks or beauty. Examining the terms of this discourse provides insight into how iraval kural first came to be normalized as a practice for creating and managing relationships between the female voice and body.

In the second part of the chapter, I turn to the ways that female voice-body relationships were constructed in films of this period, showing how a system of differentiated female voices accomplished crucial ideological work. Playback lent itself to the typification of characters, since the character traits of the onscreen body, rather than being voiced by the actress with whatever kind of voice she might have, could be accentuated by the use of a "suitable" playback voice. This became particularly pronounced in films of the early 1950s, which relied on typified female singing voices to represent distinct types of women against whom the hero and his voice could be staged.

Moreover, as I argue at the end of the chapter, while playback, with its constructed pairing of voices and bodies, theoretically makes gender crossings and cross-dressed voices possible, in this context it instead led to a greater regimentation of both gendered vocal sound and voice-body relationships. ${ }^{1}$ The ending of the flexibility and play of gender masquerade in the name of greater realism, or "naturalness," occurred in tandem with a wider societal rearticulation of gender norms. Together these constituted a process of "indexical regimentation" (Bucholtz 2011, 264): a reduction of possibilities for what kind of characters or roles can be associated with a given voice. Building on the regimentation of the qualia of the voice itself (elements such as pitch, volume, timbre, etc.), indexical regimentation is a process of controlling and narrowing the associations that are permitted to be made with those qualia. Moving from the 1940 s to the 1950 and 
beyond, we can see both of these forms of regimentation happening in the shift from singing actors and actresses to the playback system. Playback, as I will show, was a critical component of the project of redefining the ways in which women would become available to be seen and heard in the public sphere through various medial forms in the mid-twentieth century.

\section{PREHISTORIES OF PLAYBACK}

Controlling the public presence of the female form was a central part of social reform projects forged in the context of an elite nationalist movement in the late nineteenth century. During this period, as Sumanta Banerjee has shown in the context of Bengal, the policing of women's performance instituted an ideological division between "high" and "low" culture cast in gendered terms, as an opposition between kinds of women. Middle-class married women, kuțmpa strīkal (family women), were shielded by marriage and the privacy of the domestic household, while lower-class women were associated with publicness and uncontrolled sexuality (Banerjee 1989, 1990). These discourses of social reform in Bengal were highly influential on Tamil urban elites, who saw themselves as the primary agents of social reform and artistic revival in South India.

In the Tamil context, those who most represented the opposite of the respectable "family women" were the hereditary female performers of music and dance who had come to be known in colonial discourse as devadasis, a Sanskrit term meaning "servant of god." As women who lived outside of traditional marriage, devadasis were sometimes "dedicated" in marriage to temple deities; they also had relationships with and were often supported by upper-caste male patrons. In the nineteenth century, women from various devadasi communities were prominentand in the case of dance, exclusive-practitioners of the forms that would, in the 1930s, come to be classicized as "Karnatic music" and "Bharata Natyam." Devadasis became the targets of a social reform movement in the early twentieth century that aimed to put an end to the patronage structures and performance opportunities that supported them, culminating in the Madras Devadasis Act of 1947, which criminalized their lifestyle (Soneji 2012, 19). In tandem with the legal measures taken was the elite project of "reviving" these arts from their supposedly degenerate state by encouraging Brahmin and other upper-caste women to take up music and dance and begin performing them publicly (Weidman 2006, 115-121; Soneji 2012; Krishnan 2019).

In a kind of fractally recursive process, the differentiation among kinds of women was mapped onto the female figure itself, giving rise to an ideologically laden distinction between the female voice and the female body. In this moralizing discourse, the female body was imagined as available for consumption by virtue of its visibility and always ran the risk of straying into an overly Westernized realm of materialism. By contrast, the female voice was both represented as a "traditional" domain protected from the encroachments of colonialism, materialism, and the 
West (Majumdar 2008, 191) and associated with the cultivation of interiority by the new idealized middle-class female subject (Sreenivas 2003). The ideological division between the voice and the body was enabled by forms of technological mediation (Weidman 2006). In the early 1930s, the gramophone, along with the radio, enabled the emergence of respectable "family women" into the public sphere as performers - mostly singers - of South Indian classical music. The technological mediation of sound recording or radio provided a way to sing without being seen, of being private-in-public. At the same time, it helped to generate a concept of the female voice as an appealing source of naturalness and purity. Respectable musical femininity was associated with an absence of bodily performance, in contrast to the bodily gesture, facial contortions, and artifice found in the performances of male singers and courtesans (Weidman 2006, 121-35).

And crucially, in their newly classicized contexts, singing and dancing were separated, as functions to be performed by different people. Whereas earlier devadasi performance practice often involved a single performer interpreting lyrics through facial expression, bodily gestures, and her own singing voice, the upper-caste women who began to perform the newly classicized Bharata Natyam onstage and in the cinema in the 1940s did not sing as they danced (Soneji 2012; Krishnan 2019). The dividing up of functions that had previously been united in the person of the devadasi and their parceling out to different personnel constituted a powerful way in which cinema would "discipline" the figure of the devadasi (Kaali 2013), a new "distribution of the sensible" that cinema would take up and formalize through divisions of labor among singers, actresses, and dancers.

\section{MAKING CINEMA RESPECTABLE}

Many women from devadasi backgrounds found opportunities on the Tamil popular drama stage and in the new medial forms of the early twentieth century (Soneji 2012, 22-23). Between 1905 and 1930, most of the Gramophone company's production consisted of records by women singers from devadasi backgrounds (Kinnear 1994; Sampath 2010, 93-94). In the 1930s, increasingly shut out from the newly classicized arts of music and dance, they entered cinema; in fact, almost all the early female stars of Tamil cinema came from devadasi families (Soneji 2012,22 ). In the 1940s, their prominence provoked an anxious discourse about the respectability of cinema.

A short story from 1943 by the writer Ku. Pa. Rajagopalan, entitled "Studio Katai" (Studio story), portrayed this anxiety through the character of Sita, an educated, upper-caste young woman:

As soon as she'd done her MA exam, she had decided to join the talkies. She had the desire to uplift the cinema field. In cinema, actors and actresses should act with skill and feeling, she thought. If educated girls acted roles in films and showed the way, the corruptions in actresses' lives would go away, she thought. Her dream was that if the acting profession was made pure, family girls [kutumpa penkal] could easily 
get involved in it. Acting should be without obscene and dirty [acinkamāna] songs. The songs should be composed with feeling. ... Her goal was to first join the talkies herself and show the way. (Rajagopalan 1978, 78-79)

The anxieties about women's participation in the world of cinema depicted through Sita's character in this story are echoed in discourse in film magazines throughout the late 1930 s and 1940s. A popular Tamil magazine of the time, Pécum Patam, featured readers' queries in a question-answer format at the beginning of each issue, often with witty replies from the editor. This exchange, one example among many, gives a sense of the terms of the discourse:

Q. I wish to act in cinema. Can I act without doing harm to my chastity [karpu]?

A. Chastity and cinema are extreme enemies. Therefore, so as not to cause danger to the cinema industry, our cine directors fire those who hold their chastity in great esteem after the first picture-or even before it is finished! (Pēcum Pațam August 1945, 18).

By the late 1940s, numerous nondevadasi women were entering the cinema as actresses. In response to this development, a part of elite discourse on cinema focused on making cinema safe for women, both in the studios and in the theaters. A reader's letter to Pécum Patam in 1947 suggested that "family women should have more involvement in cinema. Appropriate safeguards should be put in place to protect actresses' dignity [kauravam] and chastity [karpu]" (Pécum Patam 1947). ${ }^{2}$ Echoing the political language of the day, another suggested that a natikai cankkam (actresses' association) be established to increase the suya mariyātai (selfrespect) of actresses (Pēcum Pațam April 1947, 24). And just as women in the studios needed to be protected, so, too, it was "a duty" to provide kutumpa strìkal who went to the theaters to see movies with proper conveniences. "It isn't enough that there is a four-foot wall between the women and men's section. Men are constantly ogling women, and when vulgar scenes come on screen, they will say obscene things that the women hear. Why would a kutumpa strī come to such a place? To fix this, there should be no connection between the women's and men's sections at all" (Pēcum Pațam 1945a).

Even more important to the elite project of "uplifting" cinema in the 1940s than such physical conveniences was reimagining what it meant to be an actor or actress. As M. S. S. Pandian has suggested, a central feature of elite discourse on Tamil cinema in this period was the privileging of "realism" (1996, 952), invoked to distinguish respectable acting from the loud, declamatory stage performances characteristic of company drama and from the sexually suggestive performances of devadasi actresses. Realism was also invoked to emphasize the importance of dialogue over songs (Pandian 1996, 952). A common complaint in the writings of film magazine editors and readers alike concerned the excessive number of songs that were inserted in unnecessary places in films and often served as vehicles for vulgarity and double entendre (Parthasarathy 1945, 36). Readers and editors suggested the need to replace singers who didn't know how to act-the sangita vidwans who had 
built their careers on the drama stage-with "amateur" actors from the sabhas, the upper-caste theatrical alternative to boys company drama. ${ }^{3}$ One suggested that sangita vidwans should undergo acting lessons to make their body movements less artificial and that the cinema industry should take advantage of the many "young educated men" who could act with "great skill" in character roles. "If you still want sangita vidwans to appear in talkies, do it through music concert scenes" (Shanmugham 1938). "Present day viewers expect more than just a sangita vidwan who can sing," another wrote (Pēcum Pațam 1947b).

But even as the sidelining of male singing actors was recommended in the name of realism, performing classical music and dance became respectable ways for women to appear onscreen. Because both Karnatic music and Bharata Natyam had recently been consolidated as "classical" arts, they constituted authorizing frameworks under cover of which an actress could present herself as a singer or dancer, roles that were more respected. The singing actress Bhanumathi recalled that when she was recruited to act in her first films in the late 1930s, her father laid down two conditions: first, that the hero should not be allowed to hold her hand or touch her and, second, that there should be a Thyagaraja kriti or some other Karnatic music song in the film (Vamanan 1999, 243; Ramakrishna 2000). Nationalism constituted another authorizing framework that gave women license to respectably appear and be heard in films. Nationalism, classical singing, and the emphasis on respectable womanhood came together in the voice of D. K. Pattammal, a classical singer from an orthodox Brahmin family who became famous for her renditions of Tamil "national" poet Subramania Bharathiyar's songs on records and in films.

The term natțiya națikai (dance actress) came into common use in the 1940 s to distinguish actresses who primarily performed classicized dance in films from actresses who performed character roles. A. V. Meyappa Chettiar recalled that female dance scenes with appropriately classicized movements had become a prime attraction. Making Vedala ulagam (1948), he decided to include a dance scene "that had no connection" to the plot just to "turn this into a successful picture." He asked the young dancing sisters Lalitha and Padmini, aged seventeen and fifteen at the time, who replied that they would do dance scenes only- "no character roles" (Meyappa Chettiar 1974, 77-80). "Dance actresses," though they often did come from devadasi backgrounds, stood in contrast to devadasi actresses from earlier years, who both sang and danced onscreen; dance actresses only danced, and thus others were required to sing for their dance scenes. ${ }^{4}$

\section{FRAGMENTING THE ACTRESS}

Competing with the emphasis on female respectability was an acknowledgment of the power of female stardom. Throughout the 1930s and most of the 1940s, female stars from devadasi backgrounds constituted the main attraction in Tamil films. 
The elements of kavarcci (seductiveness, sexiness) and vacikaram (attraction, allure), qualities seen to be embodied in actresses, continued to be part of the calculus of making a film. One reader, apparently fed up with the discourse of uplift, wrote in to Pécum Patam in the late 1940s: "Is it ok that on one side we have social reform movies like Velaikkari [1949] and on the other we have bhakti pictures like Meera [1945]? If we teach our girls to follow a life of bhakti from a young age, what will be the plight of men?" (quoted in Vamanan 2012, 253).

Film magazines from this period were full of jokes and exchanges about the dubious morality of actresses and acting and the incompatibility of acting with respectable domestic womanhood. For instance, in one cartoon that appeared in Kunțūci magazine in 1947, a director exhorts an actor to act with "a little more feeling" in a scene with his wife. "You have to feel that she is your wife while acting." "But sir," says the actor with an embarrassed look, "she actually is my wife!" (Kunțūi 1947b). And as this exchange from the mid-1940s indicates, actresses were portrayed as loose and deceitful women by definition:

Q. What do you call a woman who gets married to one person, but doesn't live with him, then goes and has affairs with others for fun, and then plays the role [veșam] of a pațtini [chaste wife]?

A. A “top actress [ciranta natikai]!" (cited in Vamanan 2012, 284)

Notable in these exchanges and other writings in these magazines is a particular way of discussing actresses as fragmentable entities. More than actors, actresses were frequently discussed in terms of aspects that were treated as separable: pātțu (singing), națippu (acting), nätțiyam (dance), and al laku (beauty). A recurring type of reader's question, for example, in the magazines Pécum Pațam and Kunțūci was one that asked for an evaluation or ranking of actresses or actors in terms of one of these qualities. Here are two that appeared side by side in 1947:

Q. Among M. S. Subbulakshmi, D. K. Pattammal, and N. C. Vasanthagokilam, whose music is the best? Who has the most kural inimai [voice sweetness]?

Q. Among Baby Saroja, Baby Radha, Baby Kamala, and Baby Vijayanti, who is the best in dance? (Pécum Pațam August 1947, 59)

The lists that these questions construct already assume that the actresses and singers named fall into certain types and are thus comparable. ${ }^{5}$

There were also questions that asked for a comparison of actresses in more than one aspect; for instance, this question asks about two popular singing actresses of the day:

Q. Between Rajakumari and Kannumba, who is the best in beauty, song, acting, and dance?

A. In beauty, we must give first place to Rajakumari. But for beautiful dance, Kannumba gets first place. Kannumba is best at portraying sokam [sadness] 
and viram [courage]. Rajakumari will slay your mind with love scenes. In singing, between the two, I prefer Kannumba's. (Pēcum Pațam April 1945, 20)

A persistent theme that emerges in the answers to such questions is that acting and beauty might go together but that singing and dancing, which were elevated in the moral scheme of things, rarely went with either acting or beauty. In the same issue of Pécum Pațam, the following exchange appeared:

Q. In dancing, who is best, T. R. Rajakumari or M. S. Sarojini?

A. M. S. Sarojini has learned classical dance. But she doesn't have the beautiful body to show it. Rajakumari has a beautiful appearance, but it's not possible to see any classical dance from her." (22)

While this division between physical beauty and classical dancing ability was treated as a matter of fact, the difficulty of finding a beautiful face and singing ability in the same person was more persistently remarked upon and lamented, perhaps because singing, unlike dancing, was framed as a god-given gift rather than a cultivated skill. In the midst of providing a life sketch of P. A. Periyanayaki, a singer who had lent her voice to other actresses and had also appeared in films herself, the author launched into this first-person outburst: "I am often angry at Brahma, the creator. Why? Because he will create a very beautiful person. But she won't have a good voice or even be able to speak! It will be without laya [rhythm]. To another he will give a nightingale voice-so sweet-but her facial appearance will not be good. This is the reason that the iraval kural viyaparam [trade in borrowed voices] is entering into the cine world (Kunțūci 1948c).

\section{EXPERIMENTING WITH THE FEMALE VOICE AND BODY}

The optical dubber, which enabled separately recorded sound and image to be mixed onto a single new strip of film, was introduced in the mid-193os, but it did not immediately lead to the practice of having one person act and another sing. It simply meant that an actor or actress could prerecord a song, concentrating on his or her singing without having to act simultaneously, and then later "the recorded song could be played back on an optical camera, while the actors, now in costume, mimed the lyrics they had previously sung as their actions were recorded on a separate strip of film" (Booth 2008, 39). Pioneered in Calcutta's New Theatres Studios in 1934, the practice of recording song and visual image separately soon spread to Bombay and to South Indian studios in Madras, Salem, and Coimbatore.

In the late 1930 s and 1940s, this technology enabled two forms of experimentation with female voices: postsynchronization, in which a different singing voice was substituted to go with the already filmed actress's performance, and an early form of playback, in which the visual sequence was reshot with the actress 
lip-syncing to another's voice. This experimentation happened initially with the noncentral female roles in the films rather than the heroine roles. The voices used were those of known Karnatic singers or other actresses, and they did not appear in the credits of the films.

The first instance of such experimentation came in 1937, under the auspices of producer A. V. Meyappa Chettiar, whose studio, AVM Productions, would be a prominent force in Tamil cinema for the next few decades. In AVM's third production, Nandakumar (1938), a film on the life of Lord Krishna, the singing actor T. R. Mahalingam, whose stentorian voice recalled the powerful voices of earlier drama actors, had been cast as Krishna, with singing actress T. P. Rajalakshmi as Yashoda, Krishna's foster mother. But, as the story goes, the film director and producer were unhappy with the singing voice of the actress who played Devaki, Krishna's mother. They had the idea of reshooting the song sequence with a different singer and brought in Lalitha Venkataraman, a well-known Karnatic singer with a Brahmin background, to sing the song. The visuals were reshot with the actress lip-syncing to Lalitha Venkataraman's voice (Meyappa Chettiar 1974, 17; Guy 2007).

In the early 1940s, this experimentation continued as singing actresses "lent" their voices to other actresses, and the practice began to be called iraval kural, "borrowed" or "traded voice." In Kannaki (1942), while the singing actress A. Kannumba played the role of the righteous heroine, Kannaki, and sang her own songs, iraval kural was reserved for the less morally upstanding female character. The young actress U. R. Jeevarattinam, fifteen years old at the time, acted the minor part of a Jain sadhu but also lent her voice for the character of Madhavi, the courtesan who steals Kovalan's attention away from his wife, Kannaki. The film credited U. R. Jeevarattinam for her acting role but did not credit her for singing Madhavi's songs. In the following year, Jeevarattinam lent her voice to the actress J. Susheela in Diwan bahadur (1943) but was also uncredited there.

After several years of these types of voice substitution, experimentation with female voice-body combinations involving the main heroine character began to occur. In 1945, A. V. Meyappa Chettiar and A. T. Krishnaswamy codirected Sri Valli, the story of Valli's wedding to the god Murugan. Meyappa Chettiar had originally envisioned casting K. B. Sunderambal, the singing actress known for her powerful stage voice and stage performances, as Valli. But then he decided on a different strategy, one oriented more to the potential visual allure of the film. "I wanted to give importance to Valli's character. I had to select a girl to act as Valli. I had seen the dance performances of Kumari Rukmini [ca. eighteen years old at the time]. As soon as I saw her bewitching eyes, I made the decision." Meyappa Chettiar spoke with Rukmini's father and decided to put the actress, who was also an accomplished Bharata Natyam dancer, in the role. He then turned to the question of who to cast as the hero. M. K. Thyagaraja Bhagavatar, the well-known singing actor, had performed the role of Murugan in the stage drama version of Sri Valli. "Whoever I put for the hero should be equal to MKT," he recalled thinking. He 
chose T. R. Mahalingam, whose powerful voice was felt to be like that of singing actor of the drama stage S. G. Kittapppa.

These recollections reveal the differing standards by which Meyappa Chettiar selected actor and actress. Kumari Rukmini, with her youthful beauty, classical dancing ability, and sweet singing voice of modest capabilities, did not in any way evoke the grandmotherly persona or loud, projected voice of K. B. Sunderambal; in fact, part of the reason for choosing her was, as Meyappa Chettiar said, to present "a new face" to film audiences. T. R. Mahalingam, on the other hand, AVM's selection for the actor, was deliberately chosen to evoke a premier male singing actor of the drama stage. Meyappa Chettiar recalled the attention he and his staff paid to producing the voices in the film. "We wanted to use Mahalingam's voice, which was like Kittappa's, to its fullest extent. I got my sound engineer Raghavan to help out" $(1974,36)$. After months of hard work, they shot the film, fully expecting that hero and heroine, who matched each other so well in age and looks, would make the film a success. It was only after they screened the film for the first time for distributors that they realized they had made "a big mistake": "Mahalingam's songs were in a strong, ringing [kanir $]$ voice. Valli's songs did not match that voice-they were rough and without sweetness. What to do now? ... When we watched the film we had struggled to perfect, that we expected to bring us success, the songs of Rukmini seemed to us a bit off-tune [sruti suttamillāmal]. How could we release it that way?" (Meyappa Chettiar 1974, 39).

He spoke with his audiographer, V. S. Raghavan, and the two thought up a solution. Using the voice of P. A. Periyanayaki, the classical singer whose records were well-known and who had already made a cameo appearance in AVM's 1941 film Sabapathy, they would make a simple substitution in the audio track. The process was arduous ("It is not easy to get a singer to sing exactly in sync with the lip movements of the actress on screen," Meyappa Chettiar remarked), and it was taken as an insult by the actress Rukmini, who did not give her agreement (Meyappa Chettiar 1974, 43-44). The film did not credit P. A. Periyanayaki, but the voice substitution was widely mentioned in reviews, and the film was a roaring success. Not only did audiences not mind that the actress herself was not singing, but they relished the combination of Rukmini's onscreen appearance with Periyanayaki's voice. Although this was technically postsynchronization rather than playback, it came closest to the formation that playback would bring into being in the early 1950s: the combination of a beautiful face with what was considered an ideal female singing voice that audiences recognized, not just for a minor female character but for the heroine herself. ${ }^{6}$

The mid-1940s marked an upsurge in the use of female singers, most of whom were no more than young girls themselves when they were brought into the film studios. The use of these girls' voices, whose youthful quality, with its desexualized connotation, made them distinctly different from those of the established singing actresses, was another form of experimentation. These voices were often 
combined with novel "picturizations." The cinema world had developed a taste for young girl-actresses who danced-the child prodigies "Baby" Rukmini, "Baby" Kamala, "Baby" Saroja - the last of whom was compared to Shirley Temple (Gopal 1976, 53). And because these actresses, unlike earlier devadasi actresses, did not sing while they danced, the film industry also had a need for childish-sounding female voices who could sing for their dance scenes.

Female voices and bodies were subject to various forms of multiplication. Most female singers got their first chances in child songs or group singing roles before they began to sing for heroine-actresses. These "group" or "chorus" songs featured three to five female voices singing in unison. While male voices, especially the great singing actors, always sang alone, and were usually presented as the voice of the hero himself singing, female group songs, where the voices were not necessarily presented as coming from the bodies onscreen, were common. Chorus songs were often "picturized" on dance scenes, which had become an attraction in Tamil films by the mid-1940s.

The desexualized female voice was also seen as appropriate for cross-dressed roles. Remembering this trend of the 1930s and 1940s, Pécum Patam editor P. R. S. Gopal wrote that it started with singing actress K. B. Sunderambal playing the role of Nandanar in the film of that name in 1935. Although the idea of a woman in male disguise was controversial, it also drew audience interest, and in the following years, almost all the other actresses of the day took on the roles of Narada and Krishna (Gopal 1976, 51). Apparently, the desexualized girlish voice was considered appropriate for portraying both the ascetic sage Narada and the boyish prankster Krishna. By the late 1940s, for example, several different singing actresses had acted the role of Narada in films, enough to prompt a disgruntled reader to write in to Pécum Pațam magazine criticizing the seemingly obligatory "Naratar veșam" (Naradar role) for singing actresses: "God created men and women as two different jatis. Why are we messing up God's creation by putting women in male disguise, when we have suitable male actors to play the role?" (Pécum Patam June 1945b, 37). According to Gopal, however, cinema audiences were willing to overlook unsuitable-looking "disguises" as long as the music was good (Gopal 1976, 51).

The increased demand for female singers led to the emergence, between 1945 and 1948, of a class of dedicated female singers who were decidedly not actresses. In these years, female singers such as Ravu Balasaraswati Devi, G. Krishnaveni (Jikki), and Jamuna Rani, who had begun by acting in child roles in the early 1940s, essentially gave up acting to become professional playback singers. ${ }^{7}$ Within a short time, other pathways to playback singing opened, allowing a group of professional playback singers who had no prior acting roles to emerge. Some entered the film industry through radio-for example, P. Leela and T. S. Bhagavati, who both sang their first film songs in 1947; others were brought to cinema through gramophone notoriety, such as the classical singer M. L. Vasanthakumari, who began singing for films in 1948, or through a parent's involvement in the cinema 
industry - for example, M. S. Rajeswari, who sang her first film song in 1946. The emergence of a class of dedicated singers was a step toward making the practice of iraval kural palatable.

TRADING VOICES: DEBATES ABOUT IRAVAL KURAL

In the Bombay context, those who lent their voices to actors and actresses were called "ghost" singers. Ghost singers, and the "ghost voice racket," were likened to prostitution in vitriolic commentaries from readers and editors of film magazines at this time,${ }^{8}$ attaching a powerful gendered stigma to the practice that also colored the discussion of it in the Tamil context. In this section, I trace the terms of debate about the practice of iraval kural in the 1940s, noting how, as it shifted from primarily involving women to being a more general standard, there was also a shift in attitudes. What had been viewed as shameful on moral and artistic grounds came to be viewed as a practice that should be openly acknowledged and accepted.

In the Tamil context, iraval kural, literally "traded voice," refers to both the act of borrowing and the act of lending, suggesting the exchange between actresses and female singers at this time. Actresses could "buy/get" a voice (iraval vaikku), while singers could "give/lend" their voice to an actress (iraval kotukka). If the singer was held in high esteem, the use of her singing voice in a film could be spoken of as a dhānam (tānam): a gift. This latter term was used mainly in reference to classical singers such as M. S. Subbulakshmi, P. A. Periyanayaki, and D. K. Pattammal, particularly when the voice was used as the accompaniment for classical dance scenes (Kunțūci 1948c). The terminology of the "gift" removed female voices from the dangers of the marketplace and implications of prostitution, converting the potentially problematic act of earning wealth and fame by singing for a mass audience into an auspicious act associated with respectable femininity and traditional marriage (see also Ramberg 2014, 158-59). ${ }^{9}$

In contrast, there was a stigma attached to being a singer who gave iraval kural, as evidenced by commentary about the actress and singer U. R. Jeevarattinam. With a high-pitched voice that appealed to film directors of the time, Jeevarattinam was brought to films through Modern Theatres Studio in Salem, mostly on account of her singing ability rather than any acting ability, and given songladen roles in films beginning at the age of ten. "Jeevarattinam's body is like a small sparrow," a magazine article commented about her. "Like a skylark she reaches the highest notes. We expect she'll attain acting skill very soon" (quoted in Vamanan 1999, 116). By 1943, she had also lent her voice for two actresses in films. P. R. S. Gopal wrote in 1943 that “Jeevarattinam's voice is in high demand. Her voice has been borrowed by M. S. Saroja in Kannaki and Susheela in Diwan bahadur. If Jeevarattinam wants to attain true fame, though, she should stop this iraval viyāparam [iraval business]" (quoted in Vamanan 1999, 116). The implication was that a singing actress could not afford to have her voice detached from her body 
and associated with another. Lending one's voice to other actresses amounted to a kind of promiscuity that an actress needed to avoid. ${ }^{10}$

The practice of iraval kural was described as an obstacle to the recognition of Tamil cinema as true art because it took away from the status of actors and actresses. In a letter titled "Iraval Pukal" (borrowed praise), a reader wrote that "in Tamil films to make acting good there must be națippu [acting], pātțu [singing], and alaku [good looks]. Still many more people with all these qualities might be found. That being so, giving first place roles to people who can't sing, and then buying the music of another [iraval sankkitam] - what a meaningless practice! With such a practice, neither the actor or actress, nor the world of Tamil cinema, will get recognition" (Pécum Pațam 1944).

The early discourse surrounding iraval kural in the pages of Tamil film magazines was centered on revealing the "secret" (rakaciyam) of who was actually singing. The question-answer sections in the magazines Pēcum Patam and Kunțūci were filled with questions about whether an actor was actually singing in a film and questions about "who has given iraval kural" for an actress in a particular film. Iraval kural was implied to be a means of covering up actors' and actresses' imperfections. "In talking pictures, why is music handled under cover of/behind the screen [tirai maraivu]?" asked a reader in 1938. "Don't you know?" replied the editor. "To conceal the appaswarams [wrong notes] of the actors!" (quoted in Vamanan 2012, 186). An article about the singing actress Kannumba in 1949 remarked on the rarity, by that time, of an actress singing in her own voice. While "sweet" female voices were often praised by referring to the singer as a kuyil (nightingale), this article described actresses' voices as being like the shrill cry of a peacock, a bird only interested in displaying itself. "Kannumba is not only gifted in acting, but in singing too. In this period, most stars have a mayil cariram [peacock voice]. Because of the iraval kural business only, they are surviving. Without that, these 'stars' would have had to retire long ago!" (Pēcum Pațam 1949).

Acknowledging the gendered prevalence of iraval kural for actresses in the late 1940s, film magazine discourse portrayed it as a means of covering up not just the inability but the immorality of actresses. "Why don't actors get iraval kural like actresses do?" a reader asked in 1947. "It seems," replied the editor, "that because the directors want to keep the sound of the actresses' voices just for themselves, it is necessary to get iraval kural!" (Pēcum Pațam March 1947, 65). The implication was that the iraval kural could be a kind of cover presented to the public while actresses and directors engaged in licentious activities in the studio.

The normalization of iraval kural as a women's matter-involving primarily actresses and female singers-is illustrated in a cartoon from 1948 (see fig. 1). The top frame shows an actress lip-syncing and dancing to a song being played back on the set during the film shooting as the director and lighting men watch. The bottom frame shows an irritable wife, shouting from inside the house to her husband, who is sitting on the verandah, to tell the beggar who has come to their doorstep 


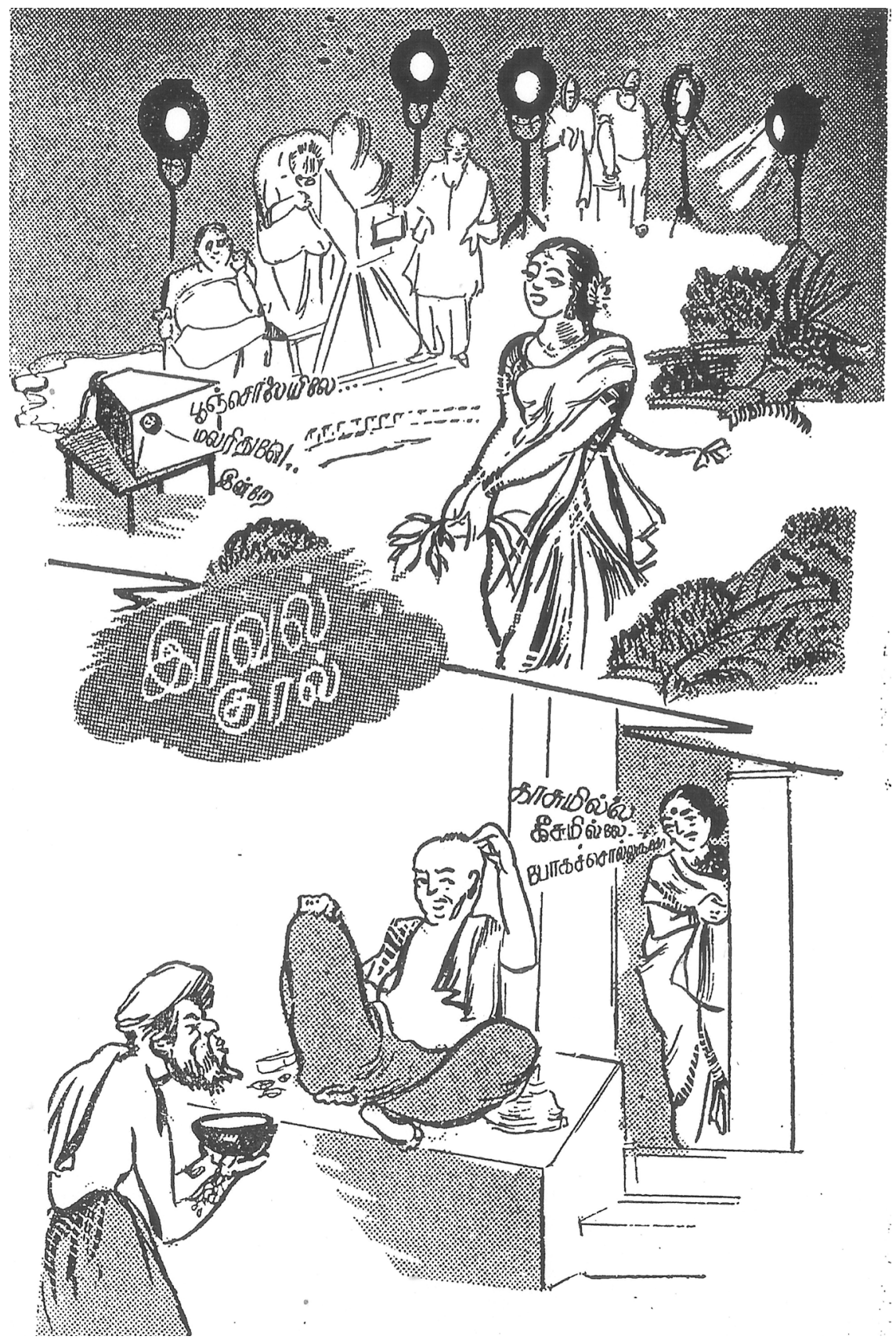

FIGURE 1. "Iraval kural [Borrowed voice]." Kuṇțūci magazine, July 1948. 
to go away. In revealing the "giver" of the iraval kural in the bottom frame to be a wife at home, the cartoon plays on gendered power relations, suggesting the "topsy turvy" world that iraval kural enables: a world in which voices are separable from bodies and have monetary value, and in which women, by lending their voices, can out-earn men; a world in which voices, rather than being controlled by bodies, are behind the scenes controlling bodies as though they are puppets. In the top frame, it is the actress who is controlled by the iraval voice, but in the bottom frame, it is the husband who finds himself acting to his wife's words (Kuntūuci 1948b). The playful juxtaposition of the studio with the domestic marital context here serves to explain, naturalize, and dismiss iraval kural as female practice.

Interspersed with these dismissive views of the practice in the pages of film magazines were, beginning in the mid-1940s, a growing number of calls for crediting iraval kural singers. In 1947, a reader remarked that iraval kural had become a "public secret" in Tamil cinema and that it would not harm the films to put the names of the singers in the credits (Kuntūuci 1947a). There seemed to be a growing consensus that crediting the singers was also essential to being able to appreciate their voice and singing skill. A reader in 1948 suggested that leaving singers uncredited interfered with filmgoers' capacity to recognize their sankita menmai (musical excellence). "The cinema directors need to make a decision. Either they need to advertise that a kural iraval-giver has given kural iraval, or from now on only those who have both acting and singing skill should be in movies" (Kunțūci 1948a). In response to a reader's question, "Is it not a disgrace [kēvalam] for those who can't sing to buy the borrowed voices of others?", P. R. S. Gopal responded: "Even though it would be very good if beauty, song, and acting could be joined in one person, it is not shameful to borrow voices. The shameful thing is that the film directors are trying to hide the fact that they are doing this (Pēcum Patam April $1945,21)$. In a subsequent issue, Gopal wrote that "an actor should get the same iraval kural for all his films. And whose voice it is should also be advertised" (Pécum Pațam 1947a). Gopal's specific focus on male actors is notable. While iraval kural was seen as mainly covering up the harsh voices or unseemly aspects of actresses, with little concern for consistent matchings between singers and actresses, this plea for actors to consistently use the same iraval voice implies that the iraval voice, rather than merely covering up an actor's deficiencies, could be an asset to the male star. ${ }^{11}$

From the initial anxiety over unattached, uncredited voices and the doubts about the morality of vocal substitution, to the acceptance of the practice and calls for crediting the singers, we can see a change in the attitude toward the "traded" (iraval) voice. ${ }^{12}$ As Neepa Majumdar has suggested, the recognition of the playback singer in the late 1940s was a means of "anchoring" the "ghost" voice within the singer's respectable and domesticized body rather than the actress's public body, thereby accentuating and supporting the moral differentiation between the female body and the female voice $(2008,192)$. While this explanation certainly captures 


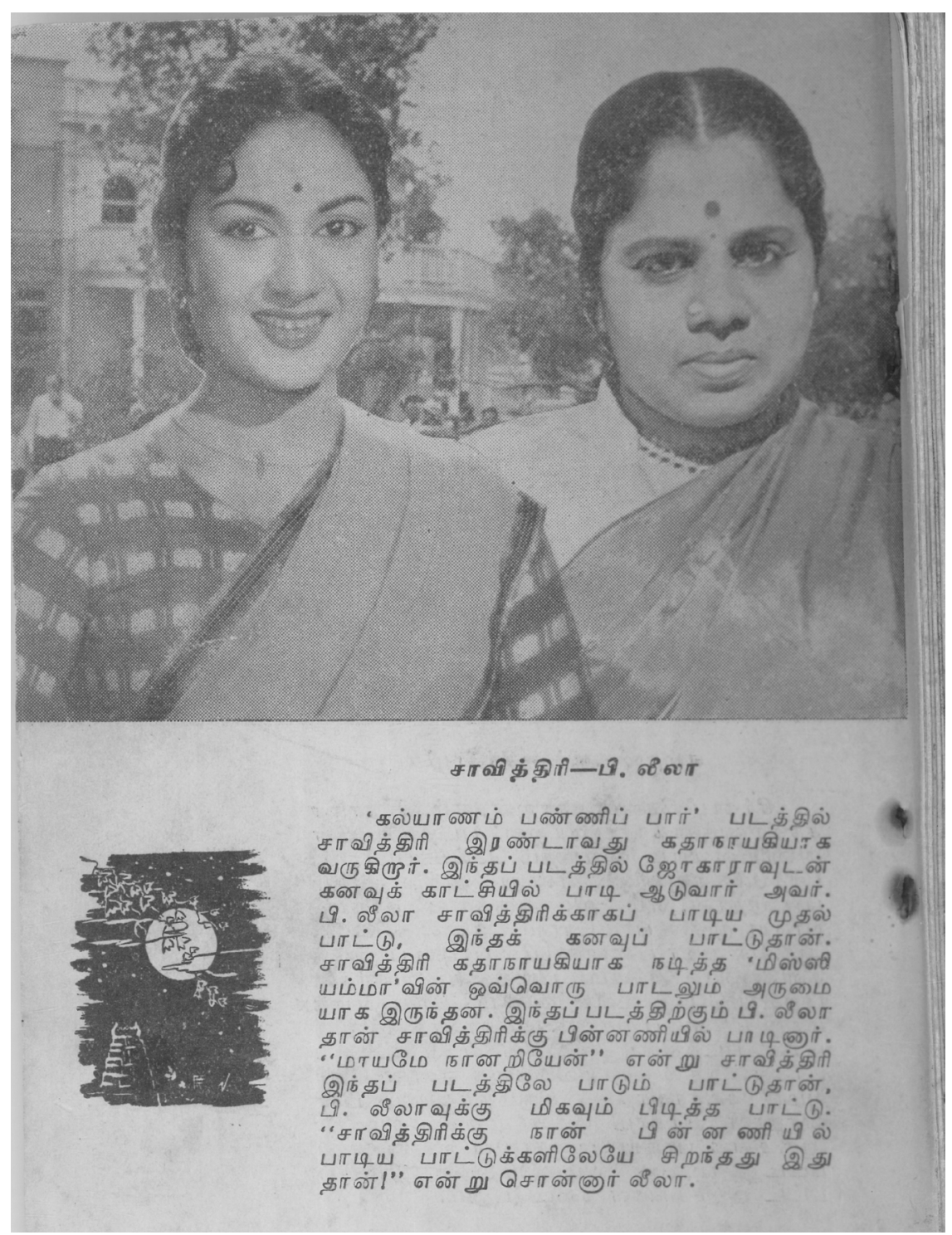

FIGURE 2. Actress Savitri with playback singer P. Leela in a feature entitled "Ōḷiyum uruvamum” (Sound and visual form) from Pēcum Pațam magazine, August 1957.

the anxious desire to manage female cinematic performance and publicity, a consideration of the terms in which vocal substitution was discussed and debated in the Tamil context suggests that this was not all that was at stake. Rather, the term iraval and its various configurations-selling, buying, borrowing, lending, trading-points to a concern not with the voice as something that had to be 
anchored and controlled but precisely with the productive effects of putting voices into circulation.

While borrowing another's voice had been regarded as morally dubious or as a negative comment on an actress's singing ability, by the 1950 s it would come to be seen as a mark of an actress's worth. Reflecting the legitimacy granted to the practice, a 1957 photo feature in Pécum Pațam entitled "Oliyum uruvamum" (Sound and visual form), for example, allowed readers to see the "sound-giving" playback singers and the "mouth-moving" actors and actresses "joined together as one" (onru sērntu) in a single picture (see fig. 2). As the term iraval faded from use and was replaced by pinnani pātakarkal (backstage or behind-screen singers), a new term, kural poruttam (voice suitability), began to be used to describe the matching of playback singers with actors and actresses. What had started as a vaguely illicit practice transformed into one that was entirely licit, acknowledged, and valued.

\section{PICTURIZING THE VOICE}

As film theorists have observed, while the addition of sound to cinema introduces the possibility of representing an organically unified body, it also sets up multiple possible matchings of voices and bodies (Doane 1980, 34; Chion 1994). In the Tamil context, even in the 1940s, before playback came into standard use, the mediation of cinematic technology enabled a range of ways that the female voice could be aligned with, or distanced from, the onscreen female body. For instance, it made possible intimate scenes showing a character's "natural" gestures and movements, as well as the close-ups of the face used in scenes of both seduction and devotion. "Picturizing" the voice-as the construction of song sequences came to be known in Indian film industries - entailed anchoring a singer's voice to a visible onscreen source or mise-en-scène that would help determine and control its meaning.

A range of possible relationships between the female voice and body is on display in Haridas (1944), an immensely popular film based on a folktale of a sinner who eventually becomes a devotee of Lord Krishna. Haridas, a young nobleman who is married, falls under the spell of Rambha, a scheming courtesan who leads him to drink and eventually lays claim to his property, driving him and his wife away. The actress playing Rambha, T. R. Rajakumari, was from a devadasi family and had already been cast in previous films as a court dancer and love interest. In Haridas, Rajakumari's love scenes were considered daring for the day and decried as vulgar and obscene by some. The role of Haridas's wife, Lakshmi, was played by N. C. Vasanthagokilam, the highly accomplished classical singer from a Brahmin background who had been previously cast in several wifely roles.

While almost every one of Rambha's song scenes is inserted as a salon performance in which she dances before male patrons and onlookers, Lakshmi's songs are accompanied not by dancing but by simply standing or minimal gesturing, and they are largely introspective scenes in which she is alone, most definitely 
not singing for an audience. In the film's major hit song, "Manmata lillaiyai," Haridas watches a dance performance by Rambha as he sings about the way the god of lust plays with the human psyche; her dance movements and abhinaya (facial and gestural movements) are carefully keyed to his song. At one point, she breaks in to sing a line of her own while continuing to dance; at another, she delivers an audible kiss to Haridas, scandalizing the male musical accompanists. In a contrasting song sequence, Lakshmi goes about her household duties-fetching water, milking a cow, tending the tulasi plant-as she sings the song "Katiravan." While Rambha's singing voice is persistently embodied in stylized performance, Lakshmi's is accompanied by seemingly natural gestures and lack of performance, a contrast that establishes the moral difference between the devadasi and the Brahmin housewife. ${ }^{13}$

In the following year, 1945, the film Meera, starring M. S. Subbulakshmi, was released to much acclaim. It was the last of four films in which Subbulakshmi, who was becoming highly acclaimed as a classical singer, would act between 1938 and 1945. All of these films featured her in roles that embodied the values of religious or wifely devotion. In Meera, Subbulakshmi played the role of the sixteenth-century princess who renounced her status and worldly possessions to become a devotee of Krishna. The film starts with Meera as a young girl who shows prodigious devotion; as a young woman, she is persuaded to marry, but after marriage, she becomes more and more devoted to Krishna. As her sainthood is demonstrated through a number of miraculous events, she develops a following and eventually leaves the palace to wander in search of Krishna.

Most of the songs in the film are inserted into the diegesis as Meera singing before Krishna, and these scenes often cut to close-ups of her face. It is notable that these scenes show Subbulakshmi not looking out at the film's viewers or at a diegetic audience but, rather, looking at the deity as she sings, a structure of gazes that keeps the song contained within a devotional framework. In addition, there are multiple references throughout the film to Subbulakshmi's real-life persona, which emphasized her singing as an expression of her own real-life devotion. The opening credits, which begin with an entire frame just for the announcement "M. S. Subbulakshmi acts in Meera" before going on to list the other actors, clearly show the importance of Subbulakshmi's extrafilmic persona to the meaning of the film, as does the prominent announcement in the credits that gramophone records of the songs are available on the HMV label. Subbulakshmi was thus doubly shielded from the performative potential of her onscreen appearance by the framing of her singing as a devotional act and by the invocation of her extracinematic career as a classical singer.

An even more extreme strategy for shielding the female singer was the diegetic framing of her songs as stage performances, which effectively marked them off from the rest of the film and distanced the song sequence from cinema as such. Nam iruvar (We two, 1947), the story of a man and woman who join the nationalist 
movement, was among several films of the 1940s featuring the voice of the wellknown classical singer D. K. Pattammal. The two songs Pattammal sings in Nam iruvar are attached to a performance attended by the hero and heroine, and Pattammal's name is announced before each song to ensure that the audience knows who is singing, in the same style as a singer's performances were announced on All India Radio. ${ }^{14}$ The placing of the songs and dance as a performance within the film effectively distances them from the film's diegesis; they act more as interludes in which the singer and dancer perform directly for the film's audience.

Cinematic technology made possible the matching of one voice with another's body or with a different scene entirely so that a singing voice could stand for the nation rather than be associated with a particular female body; it could multiply the bodies associated with a single voice and, conversely, multiply the voices associated with a single onscreen body. In "Āṭuōmē pallu pāṭuvōmē" (Let us dance, let us sing, proclaiming freedom), Pattammal's voice accompanies a Bharata Natyam performance in which the well-known child prodigy "Baby" Kamala (whose name is also announced before the scene) dances over an outline of India's map image that contains a representation of Mother India. Matched with the body of "Mother India," and further acousmatized by the suggestion of a radio broadcast, Pattammal's voice could be identified with a national myth of honor, chastity, and ideal womanhood. ${ }^{15}$

\section{THE ACOUSTIC ORGANIZATION OF DMK FILMS}

Once films began to use dedicated playback singers, the differentiation between female voices became even more pronounced. The new "social" films of the 1950 s were populated by a set of stock female characters: the chaste woman who suffers, the self-sacrificing mother, the scheming courtesan, the woman who devotes herself to god, the "new" woman working for social good, and, beginning later in the 1950s, the spoiled, Westernized rich girl. While the plots of these films tended to be organized around the changeability and transformation of the hero's character, the female characters were starkly differentiated, static types. The recognizability of these characters to the audience, and the seemingly natural division of them into good and bad, depended on what we might call—expanding on Kaja Silverman's (1988) discussion of gendered voice-body relationships in Hollywood cinema-a particular "acoustic organization."

These films brought in an emphasis on dialogue, written in an oratorical style that was associated with the DMK Party. Created by scriptwriters and actors who would play important political roles in DMK politics-C. N. Annadurai, Mu. Karunanidhi, N. S. Krishnan, K. R. Ramaswamy, and M. R. Radha-they introduced a new aestheticization of the male speaking voice, whether that of hero Sivaji Ganesan in Parasakti (1952) or antihero M. R. Radha in Ratha kanneer (1954). The emphasis on talk, the quality of the hero's voice, and the relative visual 
austerity of these films compared to the mythological films of the previous decade have been noted in critical discussions of these films and their politics (Eswaran Pillai 2015, 126-40).

The counterpart to the aestheticized male speaking voice was the complexly differentiated female singing voice. The male singing voices in these films were left relatively undifferentiated. While certain male singers like C. S. Jayaraman or M. M. Mariyappa were used as all-purpose substitutes for the male voices, the majority of the songs in these films were sung by women, the voices provided by an array of female singers, including classical singers, playback singers, and singing actresses, who were carefully cast as different character types. The clearest division was between the voices of classically trained female singers like M. L. Vasanthakumari and D. K. Pattammal, which were reserved for classicized or "national" dance or music performances that were maximally detachable from the film's characters and events, and those of professional female playback singers.

An ongoing process of mutual ideological and sonic differentiation between film music and classical music at the time helped to naturalize this order of female voices (see fig. 3). Classical music was imagined as national property, a conservative, authentically Indian, realm, while film music came to be seen as a hybrid product of modernity, open to new and foreign influences in a democratized and mass-mediated society. The contrast became particularly pronounced for female singers, especially in regard to vocal pitch and timbre. While the idealized female film voice ascended to the upper registers, classical music resolutely avoided the use of the female head voice and consequently maintained a "thicker," more "weighty," timbre commonly described as ganam. The new female playback voice that would come to dominate in the 1950s and 1960s, with its high pitch, was cultivated to be maximally different from male film voices, in contrast to earlier decades, when most singing actresses sang at a noticeably lower pitch and there was no appreciable difference in male and female vocal range. $\mathrm{M}$. K. Thyagaraja Bhagavatar, for instance, the popular singing actor of the 1930s and 1940s, had a singing voice that overlapped in range with that of T. R. Rajakumari, his female costar in many films. But, comparing female voices of the 1940s with those of the professional playback singers of the 1950s and 1960s-Jikki, Leela, Susheela, Janaki, Eswari-one can hear a distinct rise in fundamental pitch. ${ }^{16}$

The musical differentiation among types of female voices carried moral weight and could thus be used to indicate the moral status of a female character in the story. Manamagal (The bride, 1951) tells the story of the seduction of the heroine, Kumari, and her friend Vijaya by a lecherous music teacher. Even as its plot featured a lascivious and despicable Karnatic musician, the film became famous for its Karnatic song sequences, in which Kumari and Vijaya sing together, especially in the songs "Ellām inpa mayam" and "Cinnnannciru kiḷiyê." These sequences, later celebrated as standalone songs appreciated for their musical content rather than their relation to the film's story, feature M. L. Vasanthakumari singing for 


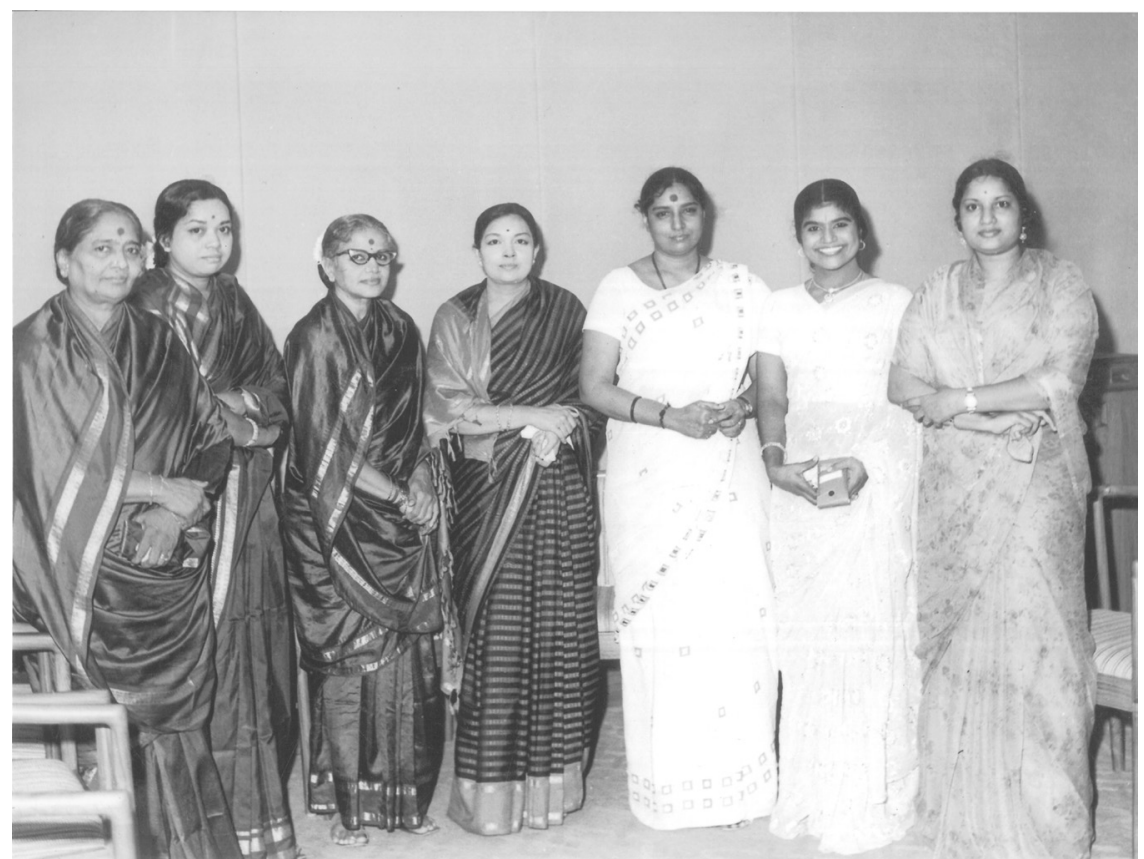

FIGURE 3. Sartorial differentiation. Left to right: classical singers D. K. Pattammal, C. P. Radha, M. S. Subbulakshmi, and R. Jayalakshmi (in silk saris), and playback singers S. Janaki,

L. R. Eswari, and Vani Jairam (in polyester saris), ca. 1972. Photo from the collection of S. V. Jayababu.

Kumari, and P. Leela, a playback singer who was noted for her classical training, singing for Vijaya; the visuals show them singing seated on a pandal, keeping tala and playing veena. But when Vijaya gets seduced by the music teacher and turns against Kumari, she appears in a Westernized dance sequence that is sung by playback singer Jikki, who had no classical training at all. A further contrast to Jikki's voice is provided by singing actress T. A. Mathuram, who plays Radha, the music teacher's abandoned former wife. Working at a school for orphans, Radha sings the musical accompaniment to a stage performance of Bharata Natyam in the orphanage. The visuals cut between Radha, seated in a white sari with her mridangam, and the school students and dancer Kuchalakumari dancing as Radha sings, in an untrained and unadorned voice, the song "Nalla penmani, mika nalla penmani" (A good woman, a very good woman), which enumerates all the things a good woman must do to maintain her respectability in Tamil culture (Krishnan 2019, 148-50).

Examining the use of these four female voices, we can see how they are positioned in a series of oppositions. At one end, the voice of M. L. Vasanthakumari, who had a parallel career as a classical concert singer, contrasts with that of P. Leela, whose career straddled classical and playback singing. Leela's voice, in 
turn, contrasts with that of Jikki, who was only a playback singer and had no classical training. The use first of Leela's and then Jikki's voice to represent Vijaya's character is meant to indicate her moral downturn. Finally, the seemingly simple and natural singing of T. A. Mathuram, a singing actress who played comedy and character roles, contrasts with Jikki's fast-paced and high-pitched singing and is used to describe the characteristics and practices of an idealized Tamil housewife.

The aestheticization of the male speaking voice and the proliferation of differentiated female singing voices feature as well in Parasakti, the most prominent of the early DMK films. The film was a critique of the inequality of Tamil society and the corruption of the Congress Party, symbolized in the struggles of a brother and sister to support themselves and maintain their dignity. Gunasekaran, the youngest of three brothers who have been living in Burma, returns to India to attend the wedding of his sister Kalyani, but he meets with a series of misfortunes and obstacles along the way. He is stripped of his money by a scheming prostitute and then reduced to begging on the streets. In the meantime, Kalyani has lost her husband and struggles to earn a living as a widow with a young child, while attempting to keep her chastity intact despite advances by lecherous moneylenders and temple priests. Driven to desperation and unable to get food, she throws her child into the river and is about to jump in herself when she is dragged away by the police. Gunasekaran is also brought to court for stealing. Eventually, Kalyani and all three brothers are reunited; her child turns out to have been rescued by Vimala, a young woman who is working for social and political reform. The final scenes of the film show the now reunited family taking up these causes by announcing the opening of a new home for orphans.

Female singing voices are important in this film; eight of the film's eleven songs are sung by women. In a pattern that was repeated in other films of these years, ${ }^{17}$ a single male singer, C. S. Jayaraman, sings the three songs for Gunasekaran's character, but three female singers, representing distinctly different backgrounds and styles, are heard in the other songs. T. S. Bhagavati, a trained classical singer from a Brahmin background who became a well-known radio artist in the 1940 s and was brought to films in the late 1940s, became famous for her renditions of "sad" songs. In Parasakti, Bhagavati's voice is used for Kalyani's character, mainly in song sequences where Kalyani sings slow, pleading, tearful lullabies to her child. In these sequences, Kalyani's body is always still. The song "Pūmalai nìyē" (O flower) is shot almost entirely with close-ups of Kalyani's tearful face as she sits slumped against the post of her house; in her other solo songs she is rocking the child or walking the streets with her child in her arms.

The voice of M. S. Rajeswari, a singer whose mother was an actress from a devadasi background, represents the new female playback voice, with its fastpaced, lilting quality. Rajeswari began working as a singer on monthly salary with AVM Productions in 1947, at the age of fifteen. Notably, in Parasakti her voice is used for two different characters. It is the voice of the prostitute/vamp "Jolly," 
who dances for Gunasekaran in "Ō racikkum sīmanē." The fast-paced singing is matched visually with Jolly's sinuous dance moves as she brings out wine glasses containing an intoxicating drink that will enable her to rob Gunasekaran. M. S. Rajeswari also provides the voice of Vimala, who dreams of marrying Gunasekaran in "Pūtu peṇnin manatai totțu" (Touch the modern girl's heart) as she dances playfully in a garden. Although Vimala, unlike Jolly, is a "good" female character, both are outside the norms of traditional womanhood; Vimala is unmarried, a "modern girl" who goes out alone and eventually has a love marriage.

M. L. Vasanthakumari's voice, meanwhile, is reserved for two extradiegetic songs that serve as a kind of frame for the film. Much like D. K. Pattammal's songs in Nam iruvar, the first of these songs, in the very first scene of the film, is presented as the musical accompaniment to a dance performance being watched by Kalyani and her husband. The song, "Vālkka vālkka," based on lyrics by the poet Bharatidasan, praises ancient Tamil culture, the fertility of Dravida Nadu, and the chaste goodness of Tamil women (Eswaran Pillai 2015, 126-27). The proscenium stage and classicized dance by a pair of girl dance actresses (Kumari Kamala and Kuchala Kumari), along with M. L. Vasanthakumari’s recognizable voice, mark this as a respectable female performance that suits Kalyani's status as a newly married woman before the misfortunes of the story befall her. And in the final scene of the film, M. L. Vasanthakumari's voice features in a chorus of female voices singing of the right of every person to live and prosper, this time visually accompanied by scenes of DMK politicians and party members gathering near the pandal (stage) erected for the inauguration of a new home for orphans. The proscenium stage and the political pandal alike, as visual framing devices, instruct viewers to hear the classical singing voice of Vasanthakumari as speaking not for particular characters in the film but to causes-the propagation of classical arts or societal and political reform - that safely remove the voice from particular bodies.

Like other DMK films of this period, Parasakti included long, alliterative monologues that showcased the speaking voice of hero-actor Sivaji Ganesan, who made his debut in this film. Writing about audience reactions to the film when it was first shown, M. S. S. Pandian remarks that audiences went to listen to the dialogues, "as if it was a film to be heard, rather than watched" $(1991,761) .^{18}$ The scriptwriter, the young Mu. Karunanidhi, had already achieved fame, and his role as the dialogue writer was prominently publicized in advertisements for the film (Eswaran Pillai 2015, 125). After the release of the film, Sivaji's monologues were also released on gramophone records along with the film's songs (Bhaskaran 1996,112 ). In the background, but working crucially to stage this male voice as the privileged speaking subject, was the array of female singing voices, carefully differentiated by timbre, style, and the extratextual personae of the singers themselves. The visuals of these song sequences offer a kind of instruction to viewers in how these voices should be heard. While the hero's spoken monologues, with their critique of religion and the Congress Party, stirred up controversy, Parasakti, 
and the DMK more generally, did not challenge gender ideologies (Pandian 1991, 769; Lakshmi 1990, 1995). To the contrary: it relied on them and perpetuated them through the seemingly natural matching of female voices with images and bodies.

\section{A MIRACULOUS RESURRECTION}

By the early 1950s, as the role of the playback singer became professionalized and the film world began to support dedicated female playback singers, singing actresses receded from prominence. ${ }^{19}$ Those who did continue to appear onscreen into the 1950 os were no longer cast in heroine roles; they were limited to character or comedy roles. Only K. B. Sunderambal, the former stage actress who specialized in devotional roles, rose in prominence in the 1950s. In her most famous film, Avvaiyyar (1953), Sunderambal was presented as a singular miracle-a unity of voice and body-resurrected from the past. The film tells the story of the Tamil saint-poetess Avvaiyyar, who as a girl shows a preternatural talent for poetry. Although her parents wish to get her married, she prays fervently to Ganesha to transform her into an old lady so that she can avoid marriage and assume the life of a wandering sage. The young Avvai sings before Lord Ganesha, "Kaṇniparuvam pōtum pōtum, annaiyin uruvam arulvāy arulvāy" (enough of this youth, bless me with a mother's form), and the young actress playing the girl Avvai, along with the playback voice of M. L. Vasanthakumari, suddenly transforms into the singing form and embodied voice of K. B. Sunderambal (see fig. 4). In the remainder of the film, the old woman Avvaiyyar wanders the Tamil country, encountering injustice and righting matters with the power of her singing voice.

Avvaiyyar's miraculous skipping of nubile womanhood and marriage mirrors Sunderambal's own long hiatus from films between 1940 and 1953. Just as the film was presented as a critical rejoinder to Parasakti and the ideology of the DMK (Eswaran Pillai 2015, 156-59), the figure of Sunderambal, clad in ascetic garb and singing in her powerful, stage-trained voice, represented the very antithesis of the playback system as it was developing in the early 1950s. As an actress who did not trade or borrow voices, Sunderambal was, by 1953, an anomaly. The singularity of her persona was emphasized thematically by the repeated miraculous effects that her voice has in the story, picturized through cinematic technologies such as cuts, montage, and time-lapse photography. This singularity was further bolstered by her extrafilmic persona as a political activist and a woman of considerable authority in her interactions with the film world. Her loud, projected voice, cultivated on the drama stage, sounded a stark contrast to the smooth, nasalized, highpitched, and microphone-dependent voices of the new female playback singers. ${ }^{20}$

Within the newly gendered vocal codes of playback, Sunderambal's projected voice was coded as androgynous. Accentuated by the desexualization of her character in Avvaiyyar and her extrafilmic persona as a long-widowed woman who had never assumed the role of a kutumpa strī, a family woman, the androgyny 


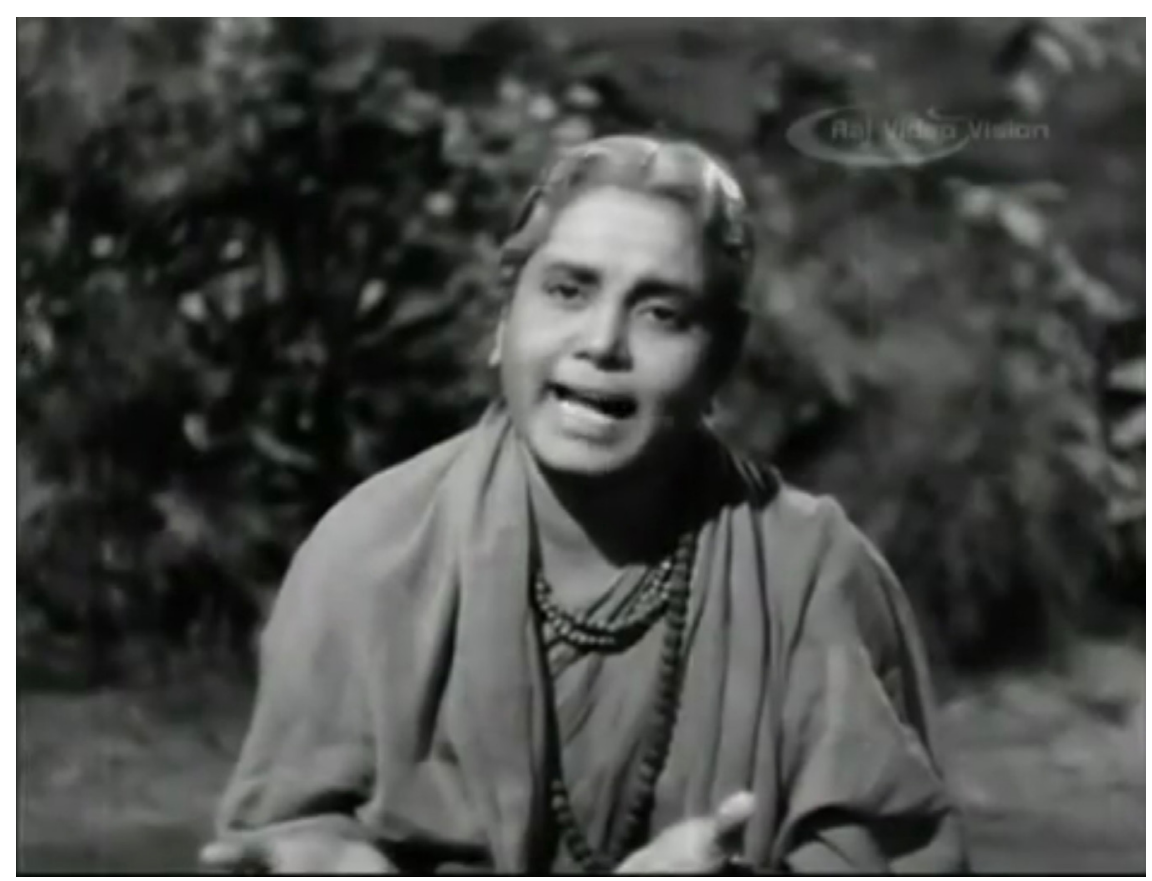

FIGURE 4. The young poetess Avvaiyyar's transformation into an old woman.

Video still and clip of K. B. Sunderambal singing in song sequence from Avvaiyyar (1953).

To watch this video, scan the QR code with your mobile device or visit DOI: https://doi.org/10.1525/luminos.104.1

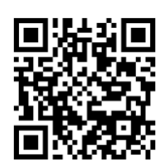

of her voice set it apart from the norm in 1953. Earlier decades of Tamil cinema had permitted a modest play with, and crossing of, gender lines in the form of the cross-dressed female voice. Female singing actresses had acted in male roles, most notably Sunderambal as Nandanar (Nandanar 1935) and M. S. Subbulakshmi as Narada (Savitri, 1941).. ${ }^{21}$ But this period of gender playfulness had ended by the time Avvaiyyar was released, giving way to a strictly gendered differentiation of voices. Even though the playback system theoretically opened up possibilities for matching male bodies with female voices and vice versa, the new female playback voice was never used for male characters. And, as we will see in the next chapter, the new male playback voice would also become appropriately masculinized. Playback, the system that presented various possibilities for how voices could be put together with bodies, in fact produced a greater regimentation of voice-body matchings. 
